\title{
PATRIOTIC DUTY OR RESENTED IMPOSITION? PUBLIC REACTIONS TO MILITARY CONSCRIPTION IN WHITE SOUTH AFRICA, 1952-1972
}

\author{
Graeme Callister \\ Department of History, University of Stellenbosch ${ }^{1}$
}

\section{Introduction}

It is widely known that from the introduction of the Defence Amendment Act of 1967 (Act no. 85 of 1967) until the fall of apartheid in 1994, South Africa had a system of universal national service for white males, and that the men conscripted into the South African Defence Force (SADF) under this system were engaged in conflicts in Namibia, Angola, and later in the townships of South Africa itself. What is widely ignored however, both in academia and in wider society, is that the South African military relied on conscripts, selected through a ballot system, to fill its ranks for some fifteen years before the introduction of universal service. This article intends to redress this scholastic imbalance.

The period of universal military service coincides with the period that saw South Africa in the world's spotlight, when defeating apartheid was the great crusade in which capitalist and communist alike could engage. It is therefore not surprising that the military of that era has also been studied. Post-1967 universal national service in South Africa has received some attention from scholars, and is generally portrayed as a resented imposition at best. Resistance to conscription is widely covered, especially through the 1980s when organisations such as the Conscientious Objectors Support Group (COSG, formed in 1980) and the End Conscription Campaign (ECC, formed in 1983) gave a more public 'face' to the anti-conscription movement. ${ }^{2}$ However, as can be seen from the relatively late

1 I would like to extend my gratitude to Professor Albert Grundlingh of the University of Stellenbosch for his comments and advice on the first draft of this article.

${ }^{2}$ See, for example, Catholic Institute of International Relations (CIIR), Out of Step, War Resistance in South Africa (London, 1989); Jacklyn Cock and Laurie Nathan 
creation of anti-conscription organisations, rejection of military service was not a natural reaction by the South African public but a reaction that evolved over a number of years.

The study on which this article is based considered the system of conscription, from the introduction of selective service in 1952 until the first largescale deployments of South African military personnel to Namibia in 1972, and explored the public reaction to that system and the way the image of the military changed during that time. The two decades covered in this study saw crucial changes in South Africa's position in the world, and it is unsurprising that the attitudes of people towards their Defence Force also changed over that period. The evolution of these attitudes was considered during the research on which this article is reporting.

\section{The geo-political status of South Africa, 1952-1972}

In 1952, South Africa was a member of the Commonwealth, under the protective umbrella of the British Empire, and through this connection the military alliance of NATO. She was a member of the victorious coalition of the Second World War, and her mineral wealth and position as guardian of the still crucial Cape Sea Route meant that she occupied an important place in Western strategy. ${ }^{3}$ Although South Africa was nothing more than a regional power at best, she participated in the Korean conflict, and was involved in a pact to send an armoured division to the Middle East to help Western forces should hostilities break out there.

The prospects of South Africa facing a direct military threat were remote. The Iron Curtain was sliding across Europe, but South Africa was a long way from the action. The continent north of South Africa was almost wholly controlled by powers friendly to South Africa, and there was little indication in the early 1950s that this was likely to change in the immediate future . The largest threats to the West came from communist China and the Soviet Union, neither of which showed any intention or indeed any capacity to launch an assault on South Africa.

As the decade of the 1950s unfolded the situation began to change. The United States made her opposition to colonialism clear and, following the

(eds), War and Society, the Militarisation of South Africa (Cape Town, 1989); and Merran Willis Phillips, The End Conscription Campaign 1983-1988: A Study of White Extra-Parliamentary Opposition to Apartheid (MA Thesis, UNISA, 2002).

3 L.H. Gann and Peter Duignan, Why South Africa Will Survive (Cape Town, 1981), pp. 164-78. 
humiliation of the 1956 Suez Crisis, Britain and France began to withdraw from their African possessions, beginning with Ghana in 1957. By the beginning of the 1960s, decolonisation was in full swing and the days of white Africa were numbered. In February 1960, British Prime Minister Harold Macmillan gave his famous 'Wind of Change' speech to the South African Parliament, which signalled Britain's opposition to South Africa's racial policies and led to a rupturing of relations between the two countries. Within 18 months South Africa had withdrawn from the Commonwealth and declared herself a republic; two years later Britain would become party to the imposition of a non-mandatory UN arms embargo on South Africa. ${ }^{4}$

The loss of the support of her Western allies was a blow to South Africa, and she responded to this by looking to herself for her own defence. However, the external threat was still minimal and, in the final analysis, the West could still be expected to come to South Africa's aid should communist powers attempt to seize the mineral resources and the Cape Sea Route on which the West relied, and which South Africa controlled. ${ }^{5}$ The threat that South Africa now had to face was to a greater extent an internal threat. The protests that led to the Sharpeville killings in 1960 signalled the intent of the black majority not to accept their fate quietly as an underclass and, despite the banning and decapitation of the ANC in the early 1960s, the Swart Gevaar was never far from white consciousness. Furthermore, in 1966 the Namibian independence movement SWAPO decided to move to armed struggle to oppose the South African occupation, and a low-intensity but ever growing insurgency broke out in the north of the territory. Initially this conflict was dealt with by the police, but by 1972 had sufficiently increased in intensity for Pretoria to order the extensive deployment of largely conscripted SADF personnel to the operational area.

\section{Traditions of military service in South Africa}

To understand the white population's reaction to compulsory military service it is necessary to look briefly at white traditions, and to examine how the military traditionally played a role in society. In South African society, it is difficult to speak of a white socio-military tradition, as like much else the military and its role in society was deeply affected by the English-Afrikaner dichotomy.

4 Ronald Hyam, The Parting of Ways: Britain and South Africa's Departure from the Commonwealth, 1951-61, Journal of Imperial and Commonwealth History, Vol. 26, No. 2, (May 1998), 157-75.

${ }^{5}$ Helmoed-Römer Heitman, South African Armed Forces (Cape Town, 1990), p. 9. 
For the Afrikaner population, especially those in the former Transvaal or the Orange Free State, the military had, since the time of the first colonists, been very much integrated with the population through the commando system. The commandos were groups of local men who banded together to form a unit in times of need. The commandos had little or no military training, and they existed essentially for the defence of land and population, and for punitive actions against transgressing neighbours. There was a great ambivalence and even mistrust of uniformed regular soldiery, especially after the Anglo-Boer War, and military formations were seen more as symbols of oppression than of national pride. ${ }^{6}$

The traditions of the British military in society differed significantly from those of the Afrikaners. For centuries the British military had used full-time volunteer soldiers and, until the beginning of the twentieth century, Britain prided itself that even in its darkest hours it had never had to resort to conscription. One commentator in the early 1900s summed up the British attitude as: '[C]onscription is only accepted by a nation in the hour of dire need, the yoke is put on when the nation is grovelling in the dust. ${ }^{7}$ Excluding the naval press-gangs, it was not until 1916 that Britain was first compelled to introduce compulsory military service, by which time the fledgling Union of South Africa and her Defence Force were already in existence. Within the British military, tradition was centred on professional units, and a great professional pride surrounded the army, often accompanied by mistrust and even scorn of things civilian. As opposed to the more inclusive commando setup in which everyone could play a part, British military units were exclusive formations in which outsiders were rarely welcome until they had proven themselves worthy. ${ }^{8}$

\section{From Union Defence Force (UDF) to South African Defence Force (SADF)}

With the formation of the Union Defence Force in 1912, the new South African government attempted to create a force that would prove acceptable to both English and Afrikaans speakers. However, only a decade after the end of the AngloBoer War most Afrikaners did not wish to be participants in what they saw as essentially an extension of the British imperial machine. The military traditions of

6 Annette Seegers, The Military in the Making of South Africa (London, 1996), p. 21.

${ }^{7}$ P.A. Silburn, The Colonies and Imperial Defence (London, 1908), p. 166.

8 J.W. Fortescue, A History of the British Army (London, 1930), Vol. XIII, pp. 56264. 
the Afrikaners were largely if unintentionally marginalised or ignored, and little was done to give Afrikaners any sense of proprietary pride in the new Defence Force. ${ }^{9}$

Not all Afrikaners turned their backs on the UDF. Many of the senior officers in the new force were ex-Boer commanders who encouraged their former comrades to join, and some Afrikaners saw service as a vehicle to recovering some independence from Britain and getting British troops off their soil. ${ }^{10}$ Despite the rejection of the UDF by some of the Afrikaner population, it has been shown that Afrikaners joined the UDF in large numbers in both World Wars. ${ }^{11}$

However, it was not until after the election of the National Party (NP) government in 1948 that the UDF began to be remoulded along Afrikaner lines. Afrikaans progressively replaced English in official terminology, and the Defence Act of 1957 (Act no. 44 of 1957) made it compulsory for all officers and noncommissioned officers to be bilingual in English and Afrikaans, a move which generally favoured Afrikaners as many English speakers were unwilling to learn another language. ${ }^{12}$ The 1957 Defence Act finally removed the last vestiges of British Imperialism from the military by changing the name of the UDF to the South African Defence Force (SADF), and substituting the Queen's Regulations with a new South African military legal system. ${ }^{13}$ In the aftermath of the Second World War, the UDF was still perceived as an English-dominated force, but by the 1960s, and certainly in the 1970s and beyond, the SADF was largely Afrikaner-controlled and -dominated.

The force that emerged from these various Acts was a blend of British and Afrikaner traditions. The army had a core of full-time soldiers, called the Permanent Force (PF), while from 1952 the main body was made up of conscripts undergoing basic training and part-timers called up for a short period each year, known as the Citizen Force (CF), whose organisation and service requirements very loosely

9 Albert Grundlingh, 'The King's Afrikaners? Enlistment and Ethnic Identity in the Union of South Africa's Defence Force During the Second World War, 1939-45', Journal of African History, Vol. 40, Issue 3, (1999), 351-65.

${ }^{10}$ Kenneth Grundy, Defence Legislation and Communal Politics, the Evolution of a White South African Nation as Reflected in the Controversy over the Assignment of Armed Forces Abroad, 1912-1976 (Athens, Ohio, 1978), p. 13.

${ }^{11}$ Grundy, Defence Legislation, p. 20; Grundlingh, 'The King’s Afrikaners?'

${ }^{12}$ Grundy, Defence Legislation, pp. 34-35.

${ }^{13}$ Bill Sass, 'The Union and South African Defence Force, 1912 to 1994', in Jakkie Cilliers and Marcus Reichardt (eds.), About Turn, the Transformation of the South African Military and Intelligence (Halfway House, 1996), p. 122. 
followed the tradition of the British-style militia. ${ }^{14}$ In addition, there were local units, called commandos, whose responsibility was local defence and who were to be called up in time of emergency. The major difference between the post-1952 Defence Force and the early UDF was that from 1952 the South African military was to be made up not of volunteers, but of men compelled to service.

\section{The introduction of conscription}

Although the Defence Act of 1912 had made provision for compulsory military service, these clauses were never activated until the Nationalist government came to power after the Second World War on account of sensitivities within the white population to service in the British Empire. Early conscription was the government's attempt to have a large potential Defence Force to call upon if needed, without having to go to the expense of maintaining an unnecessarily large peacetime military. The idea was that having a large pool of trained manpower would provide a mass deterrent for potential conventional aggressors, and that conscripts would only be used on active service if that deterrent was ineffective.

From 1952, all men of conscription age were balloted, about 30000 men annually, and a small number each year were called up. Initially these men were liable to three months of training and three short camps each, which was for a short time reduced to two months and camps only every other year. ${ }^{15}$ However, as the perceived threats to South Africa grew, so the numbers of men called up and the period for which they were required to serve increased commensurately. In 1957, about 7000 men were called up; by 1964, after Sharpeville, South Africa's exit from the Commonwealth and the UN non-mandatory arms embargo, this figure rose to $20000 .{ }^{16}$ From 1961, the period of continuous training became nine months and the $\mathrm{CF}$ requirements were increased to five camps totalling 90 days. According to Sass 'by the early $60 \mathrm{~s} . .$. with few exceptions all ballotees were selected to attend training, ${ }^{17}$ and this finally led to the decision to call up all men for military service.

In 1965, the then Minister of Defence, Jim Fouché, ordered that a committee be set up to investigate the manpower needs of the SADF. The Groenewoud Committee, as it became known, conducted wide-ranging consultations

${ }^{14}$ Sass, 'Union and South African Defence Force', p. 120.

${ }^{15}$ Sass, 'Union and South African Defence Force', p. 126.

16 CIIR, Out of Step, p. 55. NUSAS puts the figure slightly lower, at 16500 , NUSAS, In Whose Defence? Conscription and the SADF (Observatory, 1984), p. 4.

${ }^{17}$ Sass, 'Union and South African Defence Force', p. 126. 
with members of the Defence Force, MPs, and members of the public, and received 'some hundreds of memoranda from various sectors of the public'. ${ }^{18}$ The Committee made a number of findings, the most important of which was that the ballot was an unfair and inefficient system of recruitment, and that it should be replaced. It was on the recommendation of the Groenewoud Committee that universal military conscription for white adult males was introduced in 1967.

The creation of universal service in 1967 did more than just widening the net and bringing in more recruits. From 1952 until 1967 those selected through the ballot had been required by legislation to attend 'military training'. Their statutory time in the military was seen as a period of training and under normal circumstances men were not expected to see active service of any kind. Under this legislation, the government was obliged to justify the need for longer call-ups in terms of longer training times. However, the Defence Act of 1967 scrapped the term 'military training' and replaced it with the term 'national service'. Henceforth men would no longer be expected to be trained by the Defence Force, and then play the role of strategic reserves to be called up in an emergency, but during their time in uniform would be available to be used in service as the military saw fit. In practice, there was little immediate change in the use of conscripts, but by the mid-1970s national servicemen were routinely being sent to do their duty in operational areas in Namibia, something that could not have happened under the 'training' legislation. ${ }^{19}$

The vast majority of men who were called up into the Defence Force throughout this period went to do their service in the army. ${ }^{20}$ The navy and air force did take conscripts but required more technical expertise, and so were more reliant on their PF members. However, not all conscripted men went into the Defence Force. A small number each year were, with the men's consent, allocated to the Police for the duration of their service, and performed police reserve duties in much the same way as the military servicemen performed their CF camps. ${ }^{21}$

\footnotetext{
${ }^{18}$ Hansard, House of Assembly Debates (Cape Town, 1967), Vol.19, Col. 2697.

${ }^{19}$ While a 1963 Defence Amendment (Act no. 77 of 1963) made some provision for service by all members of the SADF, it did not entirely supplant the existing 'training' legislation.

${ }^{20}$ Frontline, December 1985, p. 16.

${ }^{21}$ SADF, Your Guide to National Service (Pretoria, 1982), p. 16.
} 


\section{Public reaction to conscription}

The introduction of conscription in the early 1950s was not without its critics, but there was no real opposition to the overall concept of compulsory military service. The criticism that existed was rather aimed at certain aspects of the system, such as the balloting itself. Although balloting seemed to some to be the best way to 'choose a fair cross section of recruits from urban and rural areas', ${ }^{22}$ others still thought it unfair while still others opposed the ballot as it 'impaired army traditions'. ${ }^{23}$ As few people had any alternative ideas short of abandoning the system and leaving the country almost defenceless or imposing universal service, the ballot was accepted if not particularly well liked. However, by 1967, when the climate was conducive to the imposition of universal service, many people did come out against the ballot, with even Minister of Defence P. W. Botha describing it as 'a system of fortuitous discrimination' that needed to be replaced. ${ }^{24}$

Many other aspects of early conscription were not universally popular but were still largely accepted. While the parliamentary opposition formally supported conscription, the fact that the balloting was predominantly to be done by Afrikaner NP supporters and not by the English-speaking or more moderate Afrikaansspeaking United Party (UP) supporters who had traditionally dominated the military, raised some men's ire. Sir De Villiers Graaff, who had himself fought during the Second World War, commented, 'They refused to fight during World War II. Now they are apparently listing the young South Africans who are to fight during World War III. ${ }^{25}$ As leader of the Opposition he was not amused that those who had never fought for their country should be in a position to compel others to do so.

There was also concern, even in these early years of conscription, that the military might become a NP recruiting ground and that conscripts would be a captive audience for the Nationalists to work on. Even before the system was begun Opposition MPs were receiving letters concerning this, including one which asked

${ }^{22}$ Pretoria News, 26 May 1952.

${ }^{23}$ Sir De Villiers Graaff; 'there are many of South Africa's former leading military men who believe that the ballot system impairs army traditions'. From a memo on Defence Policy issued by the UP Division of Information and Research, September 1957, p. 230. United Party archives, UNISA, Pretoria; Division of Information Subject File; Policy: Defence 1957-1974.

${ }^{24}$ Hansard (1967), Vol. 19, Col. 2694.

${ }^{25}$ UP archives; Private Collections; Sir De Villiers Graaff Collection; Defence, Acts/Bills. 
for the recruiting age to remain at 21 , as '[The Nationalist officers] will politically influence our boys, who will not be of an age yet to withstand that propaganda. ${ }^{26}$

On the political scene, public opposition to the early system of conscription was minimal to nonexistent, as both the governing NP and the opposition UP held largely the same views on the subject. As an issue, conscription held no political capital for the parties, and mention of it was unlikely to gain any votes. It is thus not surprising that in the General Election manifestos of the major South African political parties from 1948 to 1966, there is no mention of the ballot system and none of any type of compulsory military service. ${ }^{27}$ This is indicative that while the population accepted the system enough for it not to be an issue on which the government could be tackled politically, there was certainly never such positive support for the system for the NP to feel that they could score any political points from having introduced it.

The smooth introduction of conscription would also have been helped by the fact that most other Western powers, including the UK and the USA, had a similar system in place, and so the imposition on South Africa would not have seemed anything extraordinary. ${ }^{28}$ The UDF had also been woefully undermanned and under-equipped at the beginning of both World Wars, and it was recognised by those who took an interest in the Defence Force that a system of compulsory service would reduce the likelihood of South Africa being caught completely unawares again.

The complaints and criticisms about conscription that existed at this time cannot be termed a rejection of the system, for no serious calls were made to end it. They were simply concerns expressed about the workings of the system, and complaints generally fell away as in practice the system was not as bad as some may have feared. Even the concerns about the heightened Nationalist Afrikaner influence were not widely held, even in English-speaking society, and nor were they seen to be of more than slight importance, as the Defence Force continued to be seen until the 1960s at least as a force dominated by English speakers. ${ }^{29}$

${ }^{26}$ UP archives; Private Collections; Sir De Villiers Graaff Collection; Defence, Acts/Bills. Letter to Sir De Villiers Graaff dated 19 April 1952.

27 W.A. Kleynhans, SA General Election Manifestos 1910-1981 (Pretoria, 1987), pp. 311-420.

${ }^{28}$ Hansard (1961), Vol. 108, Col. 6708.

29 Rodney Warwick, 'The South African Military under Verwoerd: SADF popularisation amongst the white community, 1960-66', South African Historical Society Conference, (UCT, June 2005). 
The fact that conscription was accepted does not mean that it was liked, or that service was seen by individuals as greatly desirable. It is evident from the vocabulary of the time that military service was seen as an imposition; in the parliamentary debate on the introduction of universal service many speakers called those who were not selected to serve in the ballot as the 'lucky ones who escaped service' or complained about some men being allowed to get off 'scot-free' without serving. ${ }^{30}$ Furthermore, H. H. Smit, MP for Stellenbosch, read to the House part of a speech made by the retiring General Jacobs, in which the General claimed that 'a big percentage of trainees entered their nine months' training in a spirit of resistance'. ${ }^{31}$ Also, despite the increasing popularisation of the SADF, it was not a wholly cherished institution. On 26 January 1968, the editorial of the Star stated that 'the public is out of touch and only one step away from being out of sympathy [with the $\mathrm{SADF}],{ }^{32}$ indicating that in some constituencies the military was held in fairly low esteem. Despite these feelings, military service was submitted to by the overwhelming majority of those chosen to serve, and retained a wide if grudging support from the white South African population.

\section{Reaction to universal service}

By the time universal service was introduced in 1967 there was little background of resistance to or rejection of military service. This was especially the case after the events of the early 1960s when world opinion began to swing away from South Africa and white society began to realise that it could not necessarily rely on its Western allies for support. When the system of universal service came into force there was therefore little or no outcry from wider society, nor was there any political parliamentary opposition to speak of. The UP generally gave its support to the overall direction of the Defence Amendment Bills, and when the UP did disagree with the NP it was only about certain details. ${ }^{33}$ The second opposition party, the Progressive Party (PP), had only a lone representative in parliament in Helen Suzman, whose influence there was minimal and who was in any case more concerned with the huge racial divisions in the country than with universal national service among white men. ${ }^{34}$

${ }^{30}$ Hansard (1967), Vol. 21, Col. 7416 and Col. 7438.

${ }^{31}$ Hansard (1967), Vol. 21, Col. 7452.

${ }^{32}$ Star, 26 January 1968.

${ }^{33}$ Hansard (1967), Vols. 19-21.

${ }^{34}$ Helen Suzman, In No Uncertain Terms (Johannesburg, 1993). 
Some independent groups expressed concern over the proposed universal system. The Trade Union Council, for example, was 'alarmed at the fact that 33000 young men will be liable to call-up next year under the new training-for-all programme, ${ }^{35}$ but their views were based on economic pragmatism rather than on any conceptual opposition to national service. Indeed, little institutional opposition was voiced to the introduction of universal service, and in no way can it be seen as having been rejected by the population at large. When listing the reasons why the NP was losing popular support in 1971 and would possibly fall at the next election, the Cape Times omitted to mention conscription at all as a point of dissatisfaction among the general public. ${ }^{36}$

Even young people failed to voice any concerns in the early years of universal service. The National Union of South African Students (NUSAS), described by UP researchers as an 'anti-government Establishment, anti-capital, anti-authority, anti-social system, anti-white, anti-parliamentary system, pro-African socialism, pro-total change and entirely revolutionary in outlook', did not mention national service once in a series of seminars about the ills of the nation in $1971,{ }^{37}$ and the Young South Africans at the UP's Transvaal Provincial Congress in the same year found time to express concern about issues of yellow margarine production while neglecting to refer in any way to the military or to national service. $^{38}$

The fact that South African society made an almost seamless transition from selective service to universal service was in part at least attributable to the fact that the initial requirements of service and the sacrifices demanded continued to be comparatively low. It is also attributable to the fact that in the final years of 'selective' service the majority of balloted men were required to serve anyway, and so the legislation creating universal military service was virtually just making de jure the de facto position, and was thus never likely to cause a huge outcry in wider society. Furthermore, South Africa was not involved in a conflict, and indeed had not been since an extremely limited participation in Korea in the early 1950s. Apart from a recent police deployment in Rhodesia (Zimbabwe) and the SADF's restricted

${ }^{35}$ UP archives; Division of Information Subject File; Policy: Defence 1957-1974. Notes for Parliamentary Session 1968; Notes for Defence Group 1, 5 March 1968, p. 16.

${ }^{36}$ Cape Times, 9 November 1971.

${ }^{37}$ UP archives; Division of Information and Research; National Union of Students. Confidential Condensed Memorandum on the Activities of NUSAS, 1972.

38 UP archives; Transvaal Provincial Head Office; Congresses (Provincial 19641976). 1971 Congress, Young South Africans, Topic 2. 
role in the 1960 State of Emergency in South Africa, there were few signs that South African conscripts might actually be called upon to fight. White society also widely believed that a strong Defence Force was needed to oppose or deter any potential threat to the nation from communist-inspired revolutionaries and invaders, and that if men were called upon to go into battle it would be against these 'atheistic forces of anarchy'.

Linked to this is the fact that until the mid-1970s, the SADF was still seen as an institution concerned with the territorial defence of South Africa, and not as a pillar of the apartheid state. Although in the immediate aftermath of Sharpeville the black leader Chief Albert Luthuli had said, 'The army has a new role, not the defence of our borders, but internal security. It is clear ... this newly organised force will be turned against us as a last resort', ${ }^{39}$ and Minister of Defence, Jim Fouché, had conceded that the suppression of internal disorder was now 'an extremely important role' for the Defence Force, ${ }^{40}$ the SADF had in fact quickly faded into the background again once its internal deployments were ended. Anti-apartheid groups had yet to identify the SADF and its conscripts as oppressors, and so were content to ignore them and concentrate on attempting to campaign for political change and a liberalisation of race laws.

\section{Early objection to conscription}

In contrast to this widespread acceptance of conscription, one type of resistance which did begin to gain momentum before the mid-1970s was the issue of religious objection. Religious objection, or conscientious objection, was allowed under the King's (from 1952 the Queen's) Regulations that governed the UDF, but when these regulations were replaced by the South African military code in 1957, the provisions for conscientious objection were largely omitted. The only provision that was made was that, at the discretion of the registering officer, men with pacifist convictions may be placed in a non-combat unit within the SADF. Calls began immediately to allow conscientious objection once more, but despite petitions from religious groups to MPs to re-introduce the provisions for conscientious objection it was not catered for in the subsequent Defence Acts or Defence Amendments. ${ }^{41}$

39 CIIR, Out of Step, p. 13.

40 Hansard (1961), Vol. 106, Col. 1582.

${ }^{41}$ UP archives; Private Collections; Douglas E Mitchell Collection; Military Affairs. Letter D.E. Mitchell MP to the Religious Society of Friends in Southern Africa, dated 25 May 1956. 
However, although calls for the legalisation of conscientious objection presented a challenge to the system, in the years of selective service and the early years of universal service the challenge was not particularly strong. During this time, objectors were almost without exception members of the pacifist churches. Their objection was based on the principle of the rejection of all military service, or in some cases the rejection of any service made to a temporal authority. Their brand of objection, however, held little currency outside of their own congregations. Furthermore, as the SADF was not involved in any type of conflict and was not widely identified with racial oppression, many people with strong religious convictions could reconcile themselves with playing a non-combat role within the Defence Force and therefore avoid unpleasant clashes with the military authorities. The military authorities were also not initially particularly harsh towards objectors; before the SADF began to be deployed in Namibia in 1972, objectors were normally tried for disobeying a lawful command, which carried a 90-day Detention Barrack sentence as opposed to an 18-month sentence for failing to report or refusing to serve. $^{42}$

Nonetheless, religious objectors continually caused considerably more problems to the government than their numbers warranted, and as the years went by the complaints on this issue grew louder. Across the political spectrum, though mostly from the political left and from English churches, complaints began to appear about the treatment of pacifist objectors, who were seen as being unjustly imprisoned merely for having strong religious convictions. In 1971, even the UP, which usually took a hard line on security, added their voice to the calls, ${ }^{43}$ and in 1972 Helen Suzman was moved to speak in parliament on behalf of objectors, despite admitting that she 'held no brief for Jehovah's Witnesses'. ${ }^{44}$

However, although early conscientious objection caused the government of the day some embarrassment on moral grounds, the religious nature of the objection meant that the government's overall policies were not called into question. The anti-apartheid-inspired conscientious objections of the 1980s, when a small number of men were very publicly tried for their explicit refusal to support a system, which they considered immoral and who used their trials as a forum to diffuse their

42 CIIR, War and Conscience in South Africa, the Churches and Conscientious Objection (London, 1983), p. 26.

${ }^{43}$ UP archives; Division of Information; Subject File; Policy, Defence 1957-1974. Statement by W.V. Raw MP, Chairman, UP Defence Group, dated 16 June 1971.

${ }^{44}$ Suzman, In No Uncertain Terms, pp. 85-87. 
anti-government message, was not evident during the first two decades of conscription.

\section{Acceptance of conscription}

For some it may seem surprising that conscription was accepted almost without demur by South Africa. However, there were many reasons for men to accept their military duties in the first two decades of conscription. On a broad scale it is a well-documented psychological phenomenon that in any society the majority of people will obey the structures of authority, even if they have misgivings. Psychologist Stanley Milgram showed empirically that within an institutional environment people will comply with orders even if they believe such orders to be wrong or suspect, simply because someone in authority tells them they must. ${ }^{45}$ The level of obedience or compliance is dependent on the perceived view that exists of the institution that is giving the orders. Milgram stated that 'our compliance with the imperatives of others is tied to particular institutions and locales in our day-to-day activities, ${ }^{46}$ indicating that the more commonplace the authority the more likely it is to be obeyed. In the case of a government, obedience is as a rule endemic and so it would be expected that whether or not other motivations existed, the majority of people would comply with military service requirements.

The ability of the government to impose early conscription was helped by the fact that in general, unlike in the later years of national service, there was an absence of any pressing reasons not to serve. By the 1960s military service and the Defence Force in which it was rendered were becoming more acceptable to the whole spectrum of white South African society, ${ }^{47}$ and had not yet acquired the later stigma of being an instrument of racial repression. Furthermore, before 1972, conscripts were not sent into active operational areas in conflicts that could be seen as unjust. Some individuals may have had personal reasons not to serve, but in general service was not seen in greatly negative terms. In these circumstances, it is no surprise that the vast majority of men reported for service without protest.

Some men also had more individual motives for accepting military service. For some a sense of national pride, and even a pride in the military, was at play when they went to join their units. For the English-speaking community, the

${ }^{45}$ Stanley Milgram, Obedience to Authority, an Experimental View (London, 1974), pp. 69-70.

${ }_{46}^{46}$ Milgram, Obedience to Authority, p. 68.

47 See Warwick, 'The South African Military under Verwoerd'. 
Defence Force still represented an institution that many thousands of men had loyally served in the two World Wars and, despite the changes wrought since the NP's 1948 election victory, there was still a great deal of pride in the SADF to be found amongst English speakers. Veterans' associations, with predominantly English membership, existed throughout the country, and they kept alive English interest in the Defence Force. ${ }^{48}$ For the sons of Second World War veterans, English and Afrikaner alike, the experience of their fathers in the military persuaded some of the next generation that national service was not only their duty but also a way to follow in their fathers' footsteps and to live up to their achievements. This is essentially the scenario given by one ex-conscript who says, 'My Dad was in North Africa and Italy during the Second World War ... Probably the first photograph I ever saw of my Dad was of him in a uniform. ${ }^{49}$

Government propaganda also played a role in getting men into the military, although the effects of this were less pronounced in the first decades of compulsory service than in later years. It was not so much the propaganda aimed at the men about to be conscripted themselves but the fact that virtually from birth white South Africans were subject to the government's security discourse that helped most men to join the SADF without demur. Children were the primary focus of the propaganda effort, and from an early age were taught that communism was the enemy and that if they were not careful and failed in their duties the enemy would triumph. The process of anti-communist indoctrination continued right up until matriculation, from where most young men went straight to the military.

In the Afrikaner community especially, both parents and church were more likely to repeat the lessons taught by the government, while in the Englishspeaking community, which was traditionally politically opposed to the NP government, some parents probably encouraged their children to think less narrowly and to question the government's discourse. English-speaking universities could also have influenced some students who had yet to be conscripted with a sense of liberalism or even radicalism that led to a rejection of military service, though a number of English-speaking students maintained a pro-Establishment stance, ${ }^{50}$ and in the early years of conscription, student activists paid little heed to the topic of military service.

${ }^{48}$ UP archives; Private Collections; Sir de Villiers Graaff ; non-political, Air Force Association.

${ }^{49}$ Barry Fowler (ed.), Pro Patria (Halifax, 1995), p. 1.

${ }^{50}$ Michael Graaf (ed.), Hawks and Doves, the Pro- and Anti-conscription Press in South Africa (Durban, 1988). 
Within the Afrikaner population in particular there was also the tradition of service to the volk to live up to. For young Afrikaner boys, a position in the military and in the service of volk en vaderland was often something to aspire to and a sacrifice to be made willingly. In some Afrikaner circles, a position in the military was not only a position of pride, but also a way to climb the social ladder, as for members of the Afrikaner lower-middle class in particular, the rank of officer in the Defence Force was sought after as it would bring with it a higher status in society. ${ }^{51}$

Some men were also influenced by the idea that their country and their very civilisation may be in danger. From the mid-1960s the threat of the Rooi Gevaar, the wave of Red Danger (i.e. Communism) that was sweeping through Africa, was hammered home to boys and girls from an early age, and by the time national service came around young men were prepared to do their bit to combat it. Men often saw themselves as part of the wider struggle of the Cold War, though the view of heroically holding back the tide of unchristian and uncivilised humanity was more prevalent during the years of conflict in the 1970s and 1980s than during the first two decades of compulsory service.

The idea that military service was also a Christian service was reinforced by the Dutch Reformed Church, which wholeheartedly supported the NP government on the issue for virtually the whole period of compulsory service. ${ }^{52}$ The attitude of the Afrikaans churches to early conscription is shown in a pamphlet published by the Instituut vir Bevordering van Calvinisme, which concluded, 'Enige burger van die RSA wat reg gemotiveer is, wat intelligent meeleef met wat in SuidAfrika en die wêreld aangaan, met die regte vaderlandsliefde in die hart, sal militêre diensplig as 'n dringende noodsaak insien. ${ }^{53}$ The backing of the Afrikaans churches gave the government some moral legitimacy over the issue of conscription, and was without doubt influential in making military duty seem more of a duty and less of an imposition within the Afrikaner community.

For some conscripts the wish to uphold 'Christian civilisation' would have been strengthened by the experiences of certain African countries to the north, which had seen economic collapse, coups and civil war since the advent of majority rule.

${ }^{51}$ Philip H. Frankel, Pretoria's Praetorians, Civil-Military Relations in South Africa (Cambridge, 1984), p. 144.

52 Truth and Reconciliation Commission of South Africa Report (7 Volumes, Cape Town, 1998), Vol. 5, p. 257.

${ }^{53}$ J.F. Potgieter, Militêre Diensplig en Diensweiering (Potchesfstroom, 1974), p. 13. 
These countries were often held up as examples of black mismanagement and their example would have done nothing to allay concerns about non-racial democratic government in South Africa, ${ }^{54}$ while atrocities against whites, such as were seen in the Belgian Congo in 1960, would have made men anxious to protect themselves and their families from a similar fate. ${ }^{55}$

Some men regarded military service as positive, not for any political motive but because it offered them a chance to get out on their own. It promised to be an adventure, and it gave young men time to consider their options. Many did not consider the politics or morality of service, but instead simply considered it for what it was: a few months away from home, becoming your own man and getting sent to places you had never seen before. ${ }^{56}$ For others, joining the Defence Force offered a sense of community, inclusion, and the security that they craved, or that they thought they would miss out on if they did not do service. Men rejected on medical grounds were known to complain that they wanted to be involved in the Defence Force, and to wish to avoid the feeling of being an outsider that came with not having done military service, especially during the years of universal conscription.

While the majority went to the military due to natural obedience to the institutional authority of the government or out of pride or patriotism, there were those who did not conform to the social norms and who were inclined to disobey governmental commands. For these men, the choice to do military service was taken mainly because the cost of not doing it was too high. Refusing to serve was punishable by a prison term of up to two years, and given that the time demands of the military were not overly onerous, and that before 1972 men were not sent on active service, joining the military came to be seen as the lesser of two evils.

A young man refusing to participate in military service was furthermore likely to find himself marginalised by society and demonised by the establishment. Military service was in a sense a rite of passage that had to be completed in order to become a man. ${ }^{57}$ Not only was there disdain and vitriolic verbal attacks from all quarters accusing resisters of dereliction of duty and cowardice, a question mark was also almost automatically placed on the sexuality of a man who refused to perform

54 Frederik Van Zyl Slabbert, ed. Dene Smuts, The System and the Struggle, Reform, Revolt and Reaction in South Africa (Johannesburg, 1989), pp. 52-53.

${ }_{55}$ Giliomee, The Afrikaners, pp. 524-25.

${ }_{57}^{56}$ Fowler, Pro Patria, p. 64.

57 Fowler, Pro Patria, p. 150. 
military service. ${ }^{58}$ However, the vitriolic attacks on objectors that led the TRC to conclude that 'the State's vilification of conscripts who refused to serve in the SADF ... constitutes a violation of human rights ${ }^{59}$ mainly came in the later years of universal service, especially from 1975 onwards, when more significant numbers of men tried to avoid service.

In the early years of conscription, the numbers of men who were truly forced into the Defence Force solely out of fear of the consequences were likely to be fairly low. In all probability most young men conceded to the government's authority without the threat of punishment. Nonetheless, repressive measures and the threat of social rejection probably weighed on many men's minds, and working in combination with other factors compelled men to acquiesce to the government's wishes. This was especially the case for the part-time soldiers in the CF, who were more mature and less likely to risk acting in a way that could have dire consequences for their futures.

\section{Conclusion}

Early conscription in South Africa saw little opposition, either popularly or politically, and compliance with the military's requirements was endemic. The slight opposition that existed centred on religious opposition or opposition to certain aspects of the system, notably the unfairness of the ballot and the increasing Nationalist Afrikaner influence in the military. Early conscripts were trained as soldiers then placed on reserve, and acted as a mass deterrent to potential threats without the state being required to maintain bloated standing forces.

From 1952 until 1967 conscripts were chosen selectively by ballot to attend military training. From 1967 onward, all white males were required to perform national service, rather than attend military training, though initially the legislative changes made little practical impact. Universal service was as widely accepted as selective service had been, especially as before 1972 almost no men had been deployed in operational areas. For most men, obedience to conscription was not a conscious decision but simply something that had to be done, a kind of rite of passage to manhood that became as naturally part of a white South African male's life as going to school or getting a job. For some the idea of being able to serve their

58 D. Conway, “Every Coward’s Choice”? Political Objection to Military Service in Apartheid South Africa as Sexual Citizenship', Citizenship Studies, Vol. 8, No. 1, (March 2004), p. 25.

59 TRC Report, Vol. 5, p. 257. 
people and country helped them accept their duties, while a wish to follow in the footsteps of their forebears could also have played a part. Service also offered various men a sense of belonging and inclusion that they craved, or else it was seen as a chance to get out on their own. In the early years, some men had to be coerced into service, either through propaganda or through fear of the alternative to serving, though this was less common than in later years. Whatever motivations men may have had to accept their military duties, early conscription in South Africa was a phenomenon that caused little conflict and complaint, and drew none of the criticism and controversy that became relatively widespread during the 1980s, and that is today commonly associated with the South African conscription experience.

\section{Bibliography}

\section{Archival Sources}

\section{United Party Archives, UNISA, Pretoria}

Central Head Office

Congresses 1959-1969

Congresses 1971-1975

Relations with Political Parties and Organisations, 1956-1976

Transvaal Provincial Head Office

Congresses (Provincial) 1964-1976

Division of Information and Research

Subject File; Policy: Defence 1957-1974

National Union of Students

Speakers' Notes, 1969-70, 1972

Private Collections; Sir De Villiers Graaff Collection

Defence, Acts/Bills

Non-political, Air Force Association

National Service

Military - Career and Interests

Private Collections; Douglas E Mitchell Collection

Military Affairs

\section{Non-Archival Sources}

Catholic Institute of International Relations, War and Conscience in South Africa, the Churches and Conscientious Objection (London, 1983) 
Catholic Institute of International Relations, Out of Step, War Resistance in South Africa (London, 1989)

Cock, Jacklyn \& Nathan, Laurie (eds.), War and Society, the Militarisation of South Africa (Cape Town, 1989)

Conway, Daniel, “"Every Coward’s Choice”? Political Objection to Military Service in Apartheid South Africa as Sexual Citizenship', Citizenship Studies, Vol. 8, No. 1, (March 2004), 25-45

Fortescue, J.W., A History of the British Army (London, 1930)

Fowler, Barry (ed.), Pro Patria (Halifax, 1995)

Frankel, Philip H., Pretoria's Praetorians, Civil-Military Relations in South Africa (Cambridge, 1984)

Gann, L.H. \& Duignan, Peter, Why South Africa Will Survive (Cape Town, 1981)

Giliomee, Hermann, The Afrikaners: Biography of a People (Cape Town, 2003)

Graaf, Michael (ed.), Hawks and Doves, the Pro- and Anti-conscription Press in South Africa (Durban, 1988).

Grundlingh, Albert, 'The King's Afrikaners? Enlistment and Ethnic Identity in the Union of South Africa's Defence Force During the Second World War, 1939-45', Journal of African History, Vol. 40, Issue 3, (1999), 351-65

Grundy, Kenneth, Defence Legislation and Communal Politics, the Evolution of a White South African Nation as Reflected in the Controversy over the Assignment of Armed Forces Abroad, 1912-1976 (Athens, Ohio, 1978)

Hansard, House of Assembly Debates (Multiple Volumes, Cape Town, 1961-1972)

Heitman, Helmoed-Römer, South African Armed Forces (Cape Town, 1990)

Hyam, Ronald, 'The Parting of Ways: Britain and South Africa's Departure from the Commonwealth, 1951-61', Journal of Imperial and Commonwealth History, Vol. 26, No. 2, (May 1998), 157-75 
Kleynhans, W.A., SA General Election Manifestos 1910-1981 (Pretoria, 1987)

Milgram, Stanley, Obedience to Authority, an Experimental View (London, 1974)

National Union of South African Students, In Whose Defence? Conscription and the SADF (Observatory, 1984)

Phillips, Merran Willis, The End Conscription Campaign 1983-1988: A Study of White Extra-Parliamentary Opposition to Apartheid (MA Thesis, UNISA, 2002)

Potgieter, J.F., Militêre Diensplig en Diensweiering (Potchefstroom, 1974)

SADF, Your Guide to National Service (Pretoria, 1982)

Sass, Bill, 'The Union and South African Defence Force, 1912 to 1994', in Cilliers, Jakkie \& Reichardt, Marcus (eds.), About Turn, the Transformation of the South African Military and Intelligence (Halfway House, 1996)

Seegers, Annette, The Military In the Making of Modern South Africa (London, 1996)

Silburn, P.A., The Colonies and Imperial Defence (London, 1908)

Suzman, Helen, In No Uncertain Terms (Johannesburg, 1993)

Thompson, J.H., An Unpopular War, from afkak to bosbefok (Cape Town, 2006)

Truth and Reconciliation Commission of South Africa Report (7 Volumes, Cape Town, 1998), Vol. 5

Van Zyl Slabbert, Frederik, ed. Dene Smuts, The System and the Struggle, Reform, Revolt and Reaction in South Africa (Johannesburg, 1989)

Warwick, Rodney, 'The South African Military under Verwoerd: SADF popularisation amongst the white community, 1960-66', South African Historical Society Conference (UCT, June 2005)

\section{Newspapers and Periodicals}

Cape Times, 1971

Frontline, 1985 
Scientia Militaria, South African Journal of Military Studies, Vol 35, Nr 1, 2007. doi: 10.5787/35-1-29 67

Militaria, 1969-1972

Pretoria News, 1952

Star, 1968 